\title{
Efektivitas Diagnosis Dan Habituasi ToSM A1 Terhadap Kompetensi Hitung Dasar Intuitif Pada Mahasiswa Tingkat Akhir
}

\author{
Ade Machnun Saputra1, Tantri Ida Nursanti' ${ }^{2}$, Rini Sugiarti ${ }^{3}$, Fendy Suhariadi ${ }^{4}$ \\ 1,2,3Program Pasca Sarjana Magister Psikologi Universitas Semarang \\ Jl. Soekarno Hatta, Tlogosari Kulon, Pedurungan, Kota Semarang, Jawa Tengah 59160 \\ ${ }^{4}$ Fakultas Psikologi Universitas Airlangga \\ Kampus B UNAIR - Jl. Airlangga 4-6, Surabaya - 60286 \\ e-mail: ${ }^{1}$ ademachnun@gmail.com, ${ }^{2}$ tantri.ida@gmail.com, ${ }^{3}$ riendoe@usm.ac.iddan \\ 4fendy.suhariadi@psikologi.unair.ac.id
}

\begin{abstract}
Article History:
Abstract. This study aims to prove: the effectiveness of diagnosis and

Received

8 April 2021

Review

29 April 2021

habituation of the real number A1 level ToSM method on the basic intuitive arithmetic competency for add, subtract, multiply and divide operations. The basic intuitive arithmetic competency is cognitive ability (knowledge) and skill to operate basic arithmetic intuitively. Researchers took samples using total sampling techniques or saturated samples. In addition, the data analysis technique used is the Anava test and the

Revised

10 Mei 2021

Accepted

18 Mei 2021

Published

23 Juni 2021

Reviewer A:

Mulawarman Independent Sample T Test as well as the significance and linearity tests. As for the results of the T test hypothesis test, there is a difference in the results between the pretest and posttest ToSM in final year students with habituation of ToSM applications for 15 days. The conclusion of this study resulted in the conclusion that the ToSM level A1 method was effective as a diagnostic tool for intuitive baseline calculation on research subjects with evidence that there were still students who did not have basic intuitive arithmetic competence, namely less than 30 OPM, as well as being effective in increasing the basic intuitive arithmetic competency.

Keywords: Diagnosis, Habituation, ToSM Method, Intuitive basic arithmetic competency
\end{abstract}

ABSTRAK. Penelitian ini bertujuan untuk membuktikan: adanya efektivitas diagnosis dan habituasi metode ToSM level A1 bilangan asli terhadap kompetensi hitung dasar intuitif untuk operasi tambah, kurang, kali dan bagi. Kompetensi hitung dasar intuitif adalah kemampuan kognitif (pengetahuan) dan keterampilan mengoperasikan hitung dasar secara intuitif. Peneliti mengambil sampel dengan menggunakan teknik total sampling atau sampel jenuh. Selain itu untuk teknik analisis data yang digunakan yaitu Uji Anava dan Uji Independent Sample T Test serta uji signifikansi dan linearitas. Adapun hasil uji hipotesis uji $\mathrm{T}$ terdapat perbedaan hasil antara pretest dan posttest ToSM pada mahasiswa tingkat akhir dengan habituasi aplikasi ToSM selama 15 hari. Kesimpulan penelitian ini menghasilkan kesimpulan bahwa metode ToSM level A1 efektif sebagai alat diagnosis hitung dasar intuitif pada subjek penelitian ini dengan bukti masih ada mahasiswa yang belum memiliki kompetensi hitung dasar intuitif yakni kurang dari 30 OPM, sekaligus efektif terhadap peningkatan kompetensi hitung dasar intuitif.

Kata kunci: Diagnosis, Habituasi, Metode ToSM, Kompetensi hitung dasar intuitif 


\section{Pendahuluan}

Memasuki Abad ke 21 ditandai dengan hadirnya sebuah zaman baru yang disebut sebagai era globalisasi. Globalisasi banyak dikaitkan dengan hadirnya sebuah ideologi baru, yakni neoliberalisme, kekuasaan pasar, desentralisasi, profesionalitas, kompetensi menjadi barang yang sangat penting. Interaksi menjadi semakin tinggi malampaui batas negara dan sifat perdagangan dunia menjadi semakin kompetitif, tuntutan pelanggan semakin tinggi, product life cycle semakin pendek serta inovasi produk semakin dipentingkan. Tuntutan penyiapan sumber daya manusia yang berkualitas dan memiliki kompetensi tinggi akan menjadi sangat mendesak dan sangat penting(Suhariadi, 2013), lantas bagaimana potret sumber daya manusia Indonesia?

Hasil studi Programme for International Student Assessment (PISA) 2018 yang telah dirilis pada hari Selasa, 3 Desember 2019 menginformasikan peringkat PISA Indinesia Tahun 2018 Turun apabila dibandingkan dengan Hasil PISA tahun 2015. Studi pada tahun 2018 ini menilai 600.000 anak berusia 15 tahun dari 79 negara setiap tiga tahun sekali. Studi ini membandingkan kemampuan matematika, membaca, dan kinerja sains dari tiap anak. Untuk kategori matematika, Indonesia berada di peringkat 7 dari bawah (73) dengan skor rata-rata 379. Indonesia berada di atas Arab Saudi yang memiliki skor rata-rata 373. (Tohir, 2019)Berdasarkan hasil PISA tahun 2018 bahwa kemampuan matematika siswa belum sesuai harapan yaitu peringkat 7 dari bawah (73) dengan skor rata-rata 379 sehingga kemampuan matematika dan berpikir kritis siswa demikian juga mahasiswa perlu mendapatkan perhatian serius.

Pentingnya kompetensi hitung dasar tidak lepasdari perannya dalam segala jenis dimensi kehidupan. Misalnya memerlukan kemampuan menghitung dan mengukur. Menghitung mengarah kepada aritmatika (studi tentang bilangan) dan pada geometri (studi tentang bangun, ukuran dan posisi benda. Aritmetika dan geometri merupakan fondasi dasar dari matematika. Matematika adalah saranapendukung dari berbagai segi kehidupan yang lainnya dan juga merupakan hal yang paling urgen dalam kesuksesan komunikasi dan informasi saat ini dalam tekhnologi. Hal tersebut akan terwujud jika setiap orang memiliki kemampuan- kemampuan dalam mengembangkan potensi diri dalam berbagai hal.

Memperhatikan hasil PISA 2018 tersebut peneliti menemukan fakta yang dari penelitian tim PPMD (Pusat Pengembangan Matematika Detik) dengan instrument ToSM (Test of Second Mathematics) melaporkan pada tahun 2017 bahwa 90\% siswa SD kelas 5 dan 6 inkompeten dalam operasi hitung dasar (Tim PPMD, 2021). Apakah kondisi serupa 
terjedi di kalangan mahasiswa? Peneliti melakukan diagnosis dengan instrument yang sama. Diagnosis dalam penelitian ini adalah Asesmen diagnosis untuk memetakan kemampuan mahasiswa di kelas secara cepat, untuk mengetahui siapa saja yang inkompeten dalam hitung dasar. Sebagaimana kita ketahui kemampuan dan keterampilan siswa di dalam sebuah kelas berbeda-beda.(Pusmenjar, 2020)

Diagnosis kemampuan hitung dasar intuitif dengan metode ToSM, yang mengandung soal hitung dasar aritmetika bilangan asli sederhana untuk operasi tambah, kurang, kali dan bagi (TKKB) secara intuitif didapatkan fakta masih terdapat mahasiswa yang inkompeten dalam mengoperasikannya. Sehingga perlu dilakukan habituasi terhadap kompetensi hitung dasar intuitif. Dengan tujuan akhir mahasiswa bisa membaca angka secepat membaca kata sebagai kompetensi personal.(Faz, 2019b)

Istilah habituasi sering digunakan dalam pembalajaran dan pendidikan karakter. Habituasi adalah membiasakan kebiasaan sebagai pembaruan yang seimbang dengan perbaikan yang terus menerus yang menciptakan spiral pertumbuhan yang meningkat yang akan memberi hasil angka panjang yang menguntungkan. Kemendikbud menyatakan bahwa pembiasaan adalah proses pembentukan sikap dan perilaku yang relatif tetap dan bersifat otomatis melalui kegiatan pembelajaran yang berulang-ulang. Hal ini disampaikan dalam salinan Peraturan Menteri Pendidikan dan Kebudayaan Tentang penumbuhan Budi Pekerti tahun 2015 (Peraturan Menteri Pendidikan dan Kebudayaan RI tentang Penumbuhan Budi Pekerti, Nomor 23 Tahun 2015, 2015). Oleh sebab itu, istilah habiatuasi sangat berhubungan erat dengan sikap dan etika. (Amilia, 2018)

Kompetensi dapat digambarkan sebagai kemampuan untuk melaksanakan satu tugas, peran atau tugas, kemampuan mengintegrasikan pengetahuan, keterampilanketerampilan, sikap-sikap dan nilai-nilai pribadi, dan kemampuan untuk membangun pengetahuan dan keterampilan yang didasarkan pada pengalaman dan pembelajaran yang dilakukan(Suhariadi, 2013). Kompetensi adalah kemampuan kognitif (pengetahuan) dan nonkognitif (sikap) dan keterampilan yang dapat memprediksikan kecenderungan perilaku dalam berbagai situasi dan tugas pekerjaan, dan dapat diukur melalui kriteria spesifik atau standard tertentu (Sugiarti \& Suhariadi, 2015).

Berdasarkan beberapa pengertian kompetensi sebagaimana disebutkan di atas definisi kompetensi hitung dasar intuitif adalahketerampilan untuk menggunakan kemampuan kognitif (pengetahuan hitung aritmetika dasar operasi tambah, kurang, kali dan bagi) serta nonkognitif (sikap spontan) dalam menjawab soal operasi sederhana secacara langsung dan tanpa berpikir lebih dari dua detik. 
Habituasi dengan metode ToSM merupakan salah satu cara yang dapat membantu kesiapan belajar bahkan efektif untuk meningkatkan kemampuan hitung dasar. Sebagaimana penelitian yang dilakukan (Nur Aristiyo \& Nisa, 2020) dan (Desi Dwi J, Eleonora Dwi W, 2018). Selain efektif sebagai alat diagnosis, ToSM sekaligus dapat meningkatkan kompetensi hitung dasar intuitif dengan habituasi yang konsisten dan terukur.

Bagi seorang mahasiswa kompetensi hitung dasar operasi aritmetika bilangan asli idealnya sudah dikuasai sejak Sekolah Dasar, karena telah menjadi standar kompetensi yang sudah diajarkan dan diharapkan dapat dikuasai sejak kelas 3 Sekolah Dasar (Direktorat Tenaga Kependidikan, 2008), meskipun realita di lapangan bertambah tingginya jenjang pendidikan tidak berkorelasi positif dengan penguasaan hitung dasar secara intuitif, artinya semakin tinggi pendidikan bukan jaminan seseorang menguasai kompetensi hitung dasar.

Dibutuhkan upaya yang efektif untuk mengatasinya sehingga kompetensi dasar dapat diraih dengan cepat dalam waktu singkat. Dalam penelitian ini, selain dibiasakan ToSM dengan level A1 mahasiswa juga diberikan penjelasan dan pelatihan terkait ToSM, tidak hanya sekedar melakukan pembiasaan semata. Studi ini bertujuan untuk membuktikan adanya efektivitas diagnosis dan habituasi metode ToSM level A1 bilangan asli terhadap kompetensi hitung dasar intuitif (HDI) untuk operasi tambah, kurang, kali dan bagi pada mahasiswa semester akhir.

\section{Metode}

Alat pengumpulan data yang digunakan adalah ToSM (Test of Second Mathematics) versi digital android level A1 untuk mengukur kecepatan hitung dasar intuitif. ToSM Merupakan instrumen Matematika Detik Level A yang bertujuan untuk merangsang otak, mengasah fokus dan meningkatkan keterampilan berhitung dasar melalui latihan hitung tambah, kurang, kali dan bagi (TKKB). Matematika Detik level A sendiri adalah perpaduan antara ilmu manthiq (ilmu logika yang diperkenalkan di pesantren) dan psikologi kognitif. Fungsi TOSM untuk melatih kepekaan berpikir cepat pada operasi aritmatika dasar TKKB hingga menjadi pengetahuan atau keterampilan intuitif (Faz, 2019b).

Instrumen ToSM ini diturunkan dari konsep Matematika Detik_yang didefinisikan oleh Hadi Susanto selaku Profesor Matematika Khalifa University, Uni Emirat Arab yaitu matematika yang mengaktifkan intuisi yang terjadi dalam hitungan detik_dimaksudkan juga sebagai instrumen berlatih mengasah intuisi pada pengenalan pola rutin dan 
keberanian untuk mengungkapkannya (Faz, 2019a). Prinsip dasar teori dan mode kerja Matematika Detik adalah membagi ragam intuisi menjadi 2 moda kategori: (1) intuisi bawaan dan (2) intuisi yang dilatih. Pada moda intuisi yang dilatih adalah dengan mengubah pengetahuan rasional menjadi pengetahuan intuitif. prinsip Moda intuisi latihan inilah yang diterapkan pada instrument ToSM (Faz, 2019a)

Soal yang ada pada tes ToSM adalah deretan angka yang tersusun vertikal tanpa simbol $(+,-, x$, :). Selain itu jawaban ditulis lengkap sesuai dengan jawaban yang benar. Sebagai contoh, pada ToSM, $9+4$ jawaban ditulis apa adanya, yaitu 13. Materi ToSM tidak melibatkan perhitungan sulit karena tidak semua operasi hitung matematika dapat dijadikan sebagai pengetahuan intuitif. Sama seperti TOEFL, fokus TOSM mengarah pada pencapaian skor minimum. Jika skor ToSM minimum 30 OPM terlampaui berarti tuntas. Pada ToSM, besaran kecepatan hitung menggunakan satuan OPM singkatan dari operasi per menit (Hardian, 2019).

Dalam penelitian ini metode ToSM yang digunakan adalah versi Android yang bisa diakses secara umum dan gratis, mahasiswa diminta untuk mendownload kemudian mengerjakan ToSM Level A1 dengan 4 item operasi TKKB dengan pilihan kategori penuh (182 soal) atau setengah penuh (91 soal) dimana rumus menghitung skor pada ToSM adalah catatan lama waktu pengerjaan dalam detik dibagi dengan jumlah operasi yang benar dari 91 soal atau 182 soal kemudian dikalikan 60 dalam menit dan hasilnya adalah skala operasi permenit (OPM). Adapun tautan aplikasi ToSM ada pada link beritkut ini: https://play.google.com/store/apps/details?id=com.matematikadetik.tosm

Level A1 dari ToSM memiliki 4 item indikator ketuntasan dalam mengoperasikan hitung dasar bilangan asli (natural number) yang juga disebut bilangan bulat positif dan tidak boleh muncul 0 (nol), bilangan bulat negatif maupun pecahan. 4 item ini dikelompokkan menjadi 2 pasangan operasi: Pasangan (1) Tambah dan Kurang dan pasangan (2) Kali dan Bagi. Pasangan operasi 1 memiliki 2 kategori psikologis: mudah dan susah dimana kategori mudah memiliki pola $A+B<10$ sebanyak 20 operasi, kategori susah berpola $A+B \geq 10$ sebanyak 25 operasi. Pasangan operasi 2 juga memiliki 2 kategori psikologis: mudah dan susah dimana kategori mudah merupakan hasil operasi bilangan satu digit sebanyak 14 operasi dan kategori susah merupakan hasil operasi operasi bilangan dua digit sebanyak 31 operasi (Faz, 2019b).

Dengan merujuk materi soal seperti diatas dibuatlah pertanyaan solah yang kemudian diterjemahkan dalam aplikasi Android dengan mempertimbangkan waktu kecepatan hitung permenit dan diklasifikasikan berdasarkan nilai skornya dalam satuan 
operasi permenit (OPM): 0 - 29 OPM kriteria inkompeten sementara 30 - 70 OPM kompeten dalam hitung dasar intuitif. 30 OPM artinya dalam waktu satu menit dapat menuntaskan 30 operasi, dasar dipilihnya 30 operasi permenit ini untuk mencapai kecepatan hitung 2 detik setiap operasinya.

Untuk validitas hasil pengujian yang sudah dilakukan, antara lain yang didasarkan pada validasi isi oleh ahli materimemperoleh persentase $86,67 \%$, uji validasi ahli media memperoleh persentase 90,83\%, dan hasil implementasi aplikasi yang dilakukan di SMP Negeri 1 Slawi mendapatkan hasil yang beragam, ada yang fokusnya tinggi, ada yang fokusnya sedang, dan ada yang fokusnya rendah(Ariela Estiana, 2019). Adapun uji reliabilitas dengan keterandalan alpha Cronbach dimana $r$ hitung > r table yaitu 0.869 $>0.1968$ dengan signifikansi 0.05

Teknik analisis data yang digunakan untuk mengetahui kompetensi hitung dasar intuitif serta menguji pengaruh dan efektifitas habituasi ToSM Level A1 sebagai variabel bebas dengan kompetensi hitung dasar intuitif pada mahaiswa tingkat akhir sebagai variabel tergantung, dengan menggunakan Uji Anava dan Uji Independent Sample T Test serta uji signifikansi dan linearitas.

\section{Hasil}

Berdasarkan diagnosis kompetensi hitung dasar intuitif dengan menggunakan instrument ToSM Level A1 berbasis android didapatkan masih adanya mahasiswa yang inkompeten dalam hitung dasar intuitif meskipun mahasiswa tersebut sudah pada jenjang tingkat akhir pendidikanya di kampus.

\section{Descriptive Statistics}

\begin{tabular}{l|r|r|r} 
& N & Mean & Std. Deviation \\
\hline OpTambah & 79 & 28.7332 & 9.17674 \\
\hline OpKurang & 79 & 20.9823 & 6.33392 \\
\hline OpKali & 79 & 19.6504 & 7.52903 \\
\hline OpBagi & 79 & 18.2749 & 7.57082 \\
\hline Valid N (listwise) & 79 & & \\
\hline
\end{tabular}

Namun demikian, setelah melakukan habituasi dengan rutin bermain ToSM versi Android sembari dipandu instruktur Matematika Detik dan mengkuti pembelajaran serta pelatihan terkait dasar pemahaman dibalik instrument ToSM sebagai alat diagnosis sekaligus terapi kompetensi, hasil skor rata - ratanya meningkat dari inkompeten menjadi kompeten sebagaimana yang ditunjutkkan data berikut: 
Philanthropy Journal of Psychology

Vol 5 Nomor 1 (2021), 190-205

ISSN 2580-6076 (Print), ISSN 2580-8532 (Online)

\begin{tabular}{l|c|r|c|r|r|r}
\multirow{2}{*}{ Operasi } & \multicolumn{2}{|c|}{ Pre test } & \multicolumn{2}{|c|}{ Post Test } & \multirow{2}{*}{} \\
\cline { 2 - 5 } & Mean & Std. Deviation & Mean & Std. Deviation & Kenaikan & Persentase \\
\hline Tambah & 28.7908 & 9.17674 & 40.5890 & 9.02837 & 11.7982 & $40.98 \%$ \\
\hline kurang & 21.1176 & 6.33392 & 31.7914 & 6.91709 & 10.6738 & $50.54 \%$ \\
\hline Kali & 19.6706 & 7.52903 & 32.3076 & 9.41116 & 12.6370 & $64.24 \%$ \\
\hline Bagi & 18.2816 & 7.57082 & 29.0354 & 8.87111 & 10.7538 & $58.82 \%$ \\
\hline
\end{tabular}

Dari hasil data post test habituasi pembiasaan ToSM untuk meningkatkan skor hitung dasar intuitif di atas kita mendapatkan penjelasan bahwa nilai paling rendah dari hasil ToSM masing - masing operasi tambah, kurang, kali dan bagi adalah: 21.44, 16.93, 10.50, dan 13.13 dalam OPM (operasi permenit), sedangkan nilai tertingginya sesuai urutan sebelumnya: 65.30, 52.01, 54.58, 51.08 Dari hasil rata rata data tersebut kita bisa mendapatkan informasi bahwa rata - rata mahasiswa kompeten untuk semua operasi sederhana baik tambah, kurang, kali dan bagi setelah melakukan pembiasaan melakukan hitung dasar dengan metode ToSM.

Jika kita bandingkan rata - rata peningkatan antara pretest dan post tes didapatkan data sebagaimana ditunjukkan pada table di bawah ini dimana kenaikan masing - masing kompetensi hitung dasar intuitif untuk operasi tambah, kurang, kali dan bagi: $40.98 \%, 50.54 \%, 64.24 \%, 58.82 \%$

Sedangkan untuk mahasiswa yang skor ToSMnya mencapai ketuntasan 30 OPM antara pretest dan post tes didapatkan data sebagaimana ditunjukkan pada table di bawah ini dimana kenaikan masing - masing jumlah mahasiswa yang tuntas gagap hitung pada kompetensi hitung dasar intuitif untuk operasi tambah, kurang, kali dan bagi: 36, 45, 36, 33 orang mahasiswa.

Jumlah mahasiswa yang tuntas gagap hitung dari masing-masing operasi:

\begin{tabular}{l|r|r|r} 
Operasi & Pre Test & Post Test & Kenaikan \\
\hline Bagi & 6 & 39 & 33 \\
\hline Kali & 12 & 48 & 36 \\
\hline kurang & 8 & 53 & 45 \\
\hline Tambah & 34 & 70 & 36 \\
\hline
\end{tabular}

\section{Uji Normalitas}

Berdasarkan uji asumsi yang dilakukan, yaitu uji normalitas menggunakan besaran angka signifikasi Kolmogorof-Sminov, bahwa angka signifikansi seluruh data yang ada, pre test maupun post test dari keempat operasi hitung mempunyai angka signifikansi 
Kolmogorof-Sminov lebih besar dari 0,05 maka seluruh data adalah berdistribusi normalmaka hal ini memenuhi syarat untuk melakukan uji hipotesis.

\section{Analisa Uji Hipotesis}

Uji hipotesis dengan menggunakan teknik Analisis Regresi menggunakan bantuan SPSS (Statistical Packages For Social Science) versi 25. Adapun hasil analisis regresi dapat dilihat dari tabel berikut:

\section{Uji t - Skor ToSM Operasi [+] Tambah}

\section{Paired Samples Test}

\begin{tabular}{|c|c|c|c|c|c|c|c|c|}
\hline \multicolumn{6}{|c|}{ Paired Differences } & \multirow[b]{3}{*}{$\mathrm{t}$} & \multirow[b]{3}{*}{$\mathrm{df}$} & \multirow{3}{*}{$\begin{array}{l}\text { Sig. (2- } \\
\text { tailed) }\end{array}$} \\
\hline & \multirow[b]{2}{*}{ Mean } & \multirow{2}{*}{$\begin{array}{c}\text { Std. } \\
\text { Deviation }\end{array}$} & \multirow{2}{*}{$\begin{array}{l}\text { Std. } \\
\text { Error } \\
\text { Mean }\end{array}$} & \multicolumn{2}{|c|}{$\begin{array}{l}\text { 95\% Confidence } \\
\text { Interval of the } \\
\text { Difference }\end{array}$} & & & \\
\hline & & & & Lower & Upper & & & \\
\hline $\begin{array}{l}\text { pre - } \\
\text { post }\end{array}$ & $\begin{array}{r}- \\
11.79823\end{array}$ & 10.52842 & 1.18454 & -14.15647 & -9.43999 & -9.960 & 78 & .000 \\
\hline
\end{tabular}

Hasil analisis data yang diperoleh bahwa $t=9,960$ dan $p=0,000(p<0,05)$ artinya terdapat perbedaan signifikan antara hasil pretest dan posttest ToSM pada mahasiswa tingkat akhir sesudah pembiasaan aplikasi ToSM selama 2 pekan operasi hitung tambah.

Dari output analisis data juga didapatkan nilai mean skor ToSM operasi tambah, pre test $=28.7908$, nilai post test $=40.5890$. Dapat diartikan bahwa pembiasaan penggunaan aplikasi ToSM efektif meningkatkan kompetensi hitung dasar intuitif pada mahasiswa tingkat akhir.

\section{Uji t - Skor ToSM Operasi [-] Kurang}

\section{Paired Samples Test}

\begin{tabular}{|c|c|c|c|c|c|c|c|c|}
\hline \multicolumn{6}{|c|}{ ferences } & \multirow[b]{3}{*}{$\mathrm{t}$} & \multirow[b]{3}{*}{$\mathrm{df}$} & \multirow{3}{*}{$\begin{array}{l}\text { Sig. (2- } \\
\text { tailed) }\end{array}$} \\
\hline & \multirow[b]{2}{*}{ Mean } & \multirow{2}{*}{$\begin{array}{c}\text { Std. } \\
\text { Deviation }\end{array}$} & \multirow{2}{*}{$\begin{array}{l}\text { Std. } \\
\text { Error } \\
\text { Mean }\end{array}$} & \multicolumn{2}{|c|}{$\begin{array}{l}\text { 95\% Confidence } \\
\text { Interval of the } \\
\text { Difference }\end{array}$} & & & \\
\hline & & & & Lower & Upper & & & \\
\hline $\begin{array}{l}\text { pre - } \\
\text { post }\end{array}$ & 10.67380 & 8.15031 & .91698 & $\begin{array}{r}- \\
12.49937\end{array}$ & $\begin{array}{r}- \\
8.84823\end{array}$ & 11.640 & 78 & .000 \\
\hline
\end{tabular}

Hasil analisis data yang diperoleh bahwa $t=11,640$ dan $p=0,000(p<0,05)$ artinya terdapat perbedaan signifikan antara hasil pretest dan posttest ToSM pada mahasiswa tingkat akhir sesudah pembiasaan aplikasi ToSM selama 2 pekan operasi hitung kurang. 
Dari output analisis data juga didapatkan nilai mean skor ToSM operasi kurang, pre test $=21.1176$, nilai post test $=31.7914$. Dapat diartikan bahwa pembiasaan penggunaan aplikasi ToSM efektif meningkatkan kompetensi hitung dasar intuitif pada mahasiswa tingkat akhir.

\section{Uji t - Skor ToSM Operasi [x] Kali}

\section{Paired Samples Test}

\begin{tabular}{|c|c|c|c|c|c|c|c|c|}
\hline \multicolumn{6}{|c|}{ Paired Differences } & \multirow[b]{3}{*}{$\mathrm{t}$} & \multirow[b]{3}{*}{$\mathrm{df}$} & \multirow{3}{*}{$\begin{array}{c}\text { Sig. } \\
(2- \\
\text { tailed) }\end{array}$} \\
\hline & \multirow[b]{2}{*}{ Mean } & \multirow{2}{*}{$\begin{array}{c}\text { Std. } \\
\text { Deviation } \\
\end{array}$} & \multirow{2}{*}{$\begin{array}{l}\text { Std. } \\
\text { Error } \\
\text { Mean }\end{array}$} & \multicolumn{2}{|c|}{$\begin{array}{l}\text { 95\% Confidence } \\
\text { Interval of the } \\
\text { Difference }\end{array}$} & & & \\
\hline & & & & Lower & Upper & & & \\
\hline pre - & 12.63696 & 10.78971 & 1.21394 & 15.05373 & $10.22020^{-}$ & $10.410^{-}$ & 78 & .000 \\
\hline
\end{tabular}

Hasil analisis data yang diperoleh bahwa $t=10,410$ dan $p=0,000(p<0,05)$ artinya terdapat perbedaan signifikan antara hasil pretest dan posttest ToSM pada mahasiswa tingkat akhir sesudah pembiasaan aplikasi ToSM selama 2 pekan operasi hitung kali.

Dari output analisis data juga didapatkan nilai mean skor ToSM operasi kali, pre test $=19.6706$, nilai post test $=32.3076$. Dapat diartikan bahwa pembiasaan penggunaan aplikasi ToSM efektif meningkatkan kompetensi hitung dasar intuitif pada mahasiswa tingkat akhir.

\section{Uji t - Skor ToSM Operasi [:] Bagi}

\section{Paired Samples Test}

\begin{tabular}{|c|c|c|c|c|c|c|c|c|}
\hline \multicolumn{6}{|c|}{ Differences } & \multirow[b]{3}{*}{$l$} & \multirow[b]{3}{*}{$\mathrm{df}$} & \multirow{3}{*}{$\begin{array}{c}\text { Sig. } \\
\text { (2- } \\
\text { tailed) }\end{array}$} \\
\hline & \multirow[b]{2}{*}{ Mean } & \multirow{2}{*}{$\begin{array}{c}\text { Std. } \\
\text { Deviation }\end{array}$} & \multirow{2}{*}{$\begin{array}{l}\text { Std. } \\
\text { Error } \\
\text { Mean }\end{array}$} & \multicolumn{2}{|c|}{$\begin{array}{l}\text { 95\% Confidence } \\
\text { Interval of the } \\
\text { Difference }\end{array}$} & & & \\
\hline & & & & Lower & Upper & & & \\
\hline $\begin{array}{l}\text { pre - } \\
\text { post }\end{array}$ & $\begin{array}{r}- \\
10.75380\end{array}$ & 10.06374 & 1.13226 & $\begin{array}{r}- \\
13.00795\end{array}$ & $\begin{array}{r}- \\
8.49964\end{array}$ & -9.498 & 78 & .000 \\
\hline
\end{tabular}

Hasil analisis data yang diperoleh bahwa $t=9,498$ dan $p=0,000(p<0,05)$ artinya terdapat perbedaan signifikan antara hasil pretest dan posttest ToSM pada mahasiswa tingkat akhir sesudah pembiasaan aplikasi ToSM selama 2 pekan operasi hitung bagi.

Dari output analisis data juga didapatkan nilai mean skor ToSM operasi bagi, pre test $=18.2816$, nilai post test $=29.0354$. Dapat diartikan bahwa pembiasaan penggunaan aplikasi ToSM efektif meningkatkan kompetensi hitung dasar intuitif pada mahasiswa tingkat akhir. 
Philanthropy Journal of Psychology

Vol 5 Nomor 1 (2021), 190-205

ISSN 2580-6076 (Print), ISSN 2580-8532 (Online)

\section{Uji Signifikansi dan linearitas dengan ANOVA}

Sebagai tambahan analisis data dilakukan pula uji signifikansi dan linearitas dari masing-masing operasi hitung menggunakan uji ANOVA. Dari output SPSS tersebut didapat $\mathrm{p}$-value sebagai berikut:

\begin{tabular}{l|l|l|l}
\multicolumn{2}{l}{ Uji Signifikansi } & Uji Linieritas \\
\hline Operasi & p-value ANOVA & Operasi & p-value ANOVA \\
\hline tambah & .002 & tambah & .507 \\
\hline kurang & .014 & kurang & .691 \\
\hline kali & .038 & kali & .887 \\
\hline bagi & .021 & bagi & .788 \\
\hline
\end{tabular}

$p$-value $(p<0,05)$ regresi signifikan dan uji linearitas $p$-value $>0,05$, bersifat linier.

Dari hasil uji signifikansi dan linieritas di atas dapat disimpulkan habituasi bermain ToSM dengan level A1 berbasis android berpengaruh terhadap kompetensi hitung dasar intuitif yang ditunjukan dengan perubahan skor ToSM pada operasi tambah, kurang kali dan bagi pada mahasiswa tingkat akhir dan pengaruhnya bersifat linier.

\section{Diskusi}

Hasil penelitian ini menunjukkan bukti bahwa habituasi bermain ToSM Level A1 berbasis android berpengaruh dalam meningkatkan skor ToSM yang menjadi indikator kompetensi hitung dasar intuitif pada mahasiswa. Hal tersebut menjadikan temuan baru terkait dengan implementasi instrument ToSM di dunia akademis yang baru sebatas jenjang pendidikan SD, SMP dan SMA, sementara subjek penelitian ini merupakan jenjang perguruan tinggi yang terbukti masih didapati mahsiswa yang inkompeten atau gagap hitung. Penelitian terkait ToSM sebelumnya seperti yang dilakukan (Nisa, 2018) meneliti keefektifan ToSM terhadap kemampuan koneksi matematis siswa kelas VII pada materi aritmatika sosial.

Peneliti menemukan dari hasil wawancara dengan sebagian besar peserta dan dosen pembimbing adanya gangguan psikis berupa ketakukan mendapatkan nilai skor yang jelek, ragu dalam menjawab soal dengan cepat, rasa minder pada teman yang lain karena tidak suka dengan hitung - hitungan, bahkan ada peserta yang sempat tidak mau mencoba karena takut. Temuan ini dikuatkan dengan hasil observasi penelitian dari tim PPMD (Pust Pengembangan Matematika Detik) yang menyebutkan adanya sumbatan psikologis pada siswa yang belum tuntas mencapai skor 30 OPM, terbuktinya uji hipotesis menegaskan bahwa pada dasarnya siswa di sekolah juga termasuk mahasiswa bahwa mereka cukup pintar dan dapat mengikuti instruksi pembelajaran dan dapat menjalankan 
tahapan belajar termasuk di kampus dengan bukti mereka telah diterima di perguruan tinggi terlebih subjek penelitian ini adalah mahasiswa tingkat akhir artinya mereka telah teruji dan lulus hingga ke jenjang akhir perkuliahan. Dengan habituasi yang terprogram dan dalam waktu yang relatif singkat skor kompetensi hitung dasar intuitif dapat tercapai. Hal apa saja yang menyumbat tersebut dijelaskan (Faz, 2019a) ada empat jenis, yaitu 1) kebiasaan berpikir yang terlampau terfokus pada pengetahuan (masa lalu); 2) kebiasaan berpikir dan bertindak terlampau meniru pola textbook, serial (satu jalur), terkekang, lambat, dan membosankan; 3) kebiasaan menceraiberaikan ilmu, mengasingkan satu cabang ilmu dengan cabang ilmu lainnya (berpikir isolatif); 4) kebiasaan tidak menghargai individualitas; kebiasaan mengabaikan pengalaman dan pemikiran sendiri.

Penelitian ini juga membuktikan diagnosis untuk memetakan kompetensi hitung dasar intuitif menggunakan instrumen ToSM berbasis android semakin mudah khususnya di daerah yang sudah mendapatkan kemudahan akses internet semisal diperkotaan. Apa lagi disaat pandemi covid-19 yang hampir sebagian besar kegiatan belajar mengajar diadakan secara daring dan masih jarang yang melakukan secara luring. Kondisi ini menjadikan kegiatan belajar mengajar akan banyak mengalami hambatan baik internal maupun eksternal dari sisi guru pengajar maupun siswa. Gangguan eksternal diantaranya datang justru dari akses internet yang mana hal ini dapat mengalihkan konsentrasi peserta didik dari pelajaran yang sekolah berikan. Bahkan adiksi internet merupakan salah satu dampak negatif yang dapat terjadi dan meningkat pada pelajar selama pembelajaran jarak jauh di masa pandemi COVID-19 (Annastasya G. Ratulangi, Bernabas H. R. Kairupan, 2021). ToSM sebagai instrument terapi dapat menjadi alternatif mengurangi dampak negatif dari adiksi internet.

Sebagai salah satu instrumen turunan dari Matematika Detik (MD), ToSM memiliki tujuan sebagai berikut: (1) menjaga kebugaran otak, (2) meningkatkan ketajaman pikiran dan daya konsentrasi, dan (3) meningkatkan keterampilan hitung dasar hingga menjadi pengetahuan intuitif (Faz, 2020). Tujuan pertama ToSM untuk menjaga kebugaran otak selaras dengan penelitian ilmuwan neurosains Jepang yang dikenal karena penampilannya dalam serial permainan video Brain Training/Brain Age untuk Nintendo DS dan Nintendo 3DS dan dikenal sebagai "devil yang membongkar kode demensia" Ryuta Kawashima dalam Latih Otak Anda Lagi, membuktikan bahwa cara terbaik merangsang otak adalah dengan mengerjakan perhitungan yang gampang dengan cepat dan membaca dengan keras. Dua kegiatan tersebut akan menyalakan otak seperti saklar lampu. Penelitian lanjutan Ryuta Kawashima ditemukan bahwa dua kegiatan tersebut bahkan dapat 
membantu orang mempertahankan kejernihan daya pikir dan menghilangkan kepikunan (DR Kawashima, 2009). Lebih lanjut metode Kawashima yang juga menyajikan soal hitung dasar dengan mudah ternyata efektif juga dalam meningkatkan kemampuan matematika anak penyandang autis. Autisme atau autism spectrum disorder (ASD) merupakan gangguan perkembangan pada anak yang menyebabkan kemampuan komunikasi dan sosialisasi anak terganggu (Endro Tri Susdarwono, 2020).

Habituasi bermain ToSM dengan tujuan meningkatkan ketajaman pikiran, daya tahan diri dan konsentrasi menyelesaikan seluruh soal ToSM hingga tuntas mencapai kecepatan 30 OPM nampaknya akan mendukung kecerdasan adversitas (Adversity Quotient) mahsiswa. Dari pengamatan peneliti terhadap subjek meskipun awalnya kesulitan menuntaskan target minimal 30 OPM namun habituasi bermain ToSM level A1 ternyata dapat meningkatkan rasa percaya diri dan menghargai keputusan spontan karena ada aturan penting dalam bermain ToSM berbasis android yang tersirat harus diperhatikan yaitu ketika ada kesalahan menjawab, segera setelah itu muncul soal - soal yang lain dimana pemain ToSM tidak diberikan kesempatan untuk memperbaiki kesalahan yang dibuat, bahkan dalam modul ToSM yang berbentuk lembar kerja kesalahan yang dibetulkan terhitung 2 kali salah. hal ini diterapkan agar pemain ToSM lebih menghargai proses yaitu berani mengambil keputusan dan menghargai keputusan yang diambil serta mempertanggung jawabkannya.

Adversity quotient (AQ) dapat disebut dengan kecerdasan adversitas, menurut Stoltz dalam (Sugiarti et al., 2020) Adversity Quotient merupakan suatu kemampuan seseorang dalam mengatasi kesulitan dan mengubah kesulitan dalam meraih kesuksesan. Masih menurut Stoltz Adversity Quotient dipengaruhi oleh daya saing, produktivitas, kreativitas, motivasi, mengambil resiko, perbaikan, ketekunan, belajar dan merangkul perubahan. Penjelasan ini menguatkan tujuan dari dibuatnya instrument ToSM untuk meningkatkan ketajaman pikiran dan daya konsentrasi. Dengan habituasi bermain ToSM AQ pada subjek penelitian diharapkan juga akan meningkat hal ini didasarkan pada adanya daya juang subjek penelitian dalam menggapai skor ketuntasan minum 30 OPM yang tiak mudah dilakukan tanpa motivasi dalam diri untuk bertahan dari tantangan dan kesulitan soal ToSM karena banyak soal operasi disertai dengan batasan waktu tertentu. Sebagaimana diketahui siswa yang memiliki adversity quotient tinggi dapat membangkitkan motif, membangkitkan daya gerak, atau menggerakkan seseorang atau diri sendiri untuk berbuat sesuatu dalam rangka mencapai suatu kepuasan atau tujuan (Sugiarti et al., 2020). Mahsiswa yang memiliki adversity quotient yang tinggi, akan 
mampun menghadapi tantangan setelah mereka lulus serta mendorong motivasi berprestasi dalam karir maupun studi lanjut setela menyelesaikan kuliah strata satu, demikian juga sebaliknya adversity quotient yang dimiliki mahsiswa itu rendah maka motivasi berprestasi nya pun turun, cenderung mudah menyerah, mudah putus asa, cenderung pesimis, kurang terbuka, dan kurang bertangggungjawab.

\section{Simpulan}

Berdasarkan hasil temuan, analisis, dan pembahasan dalam penelitian ini dapat disimpulkan bahwa metode ToSM (Test of Second Mathematics) yang berbasis android level A1 efektif sebagai alat diagnosis hitung dasar intuitif pada subjek penelitian ini yang dibuktikan dengan masih adanya mahasiswa yang belum mencapai skor operasi minimum30 OPM (operasi per menit) yang dengan hasil minimum tersebut seorang mahasiswa dapat dinyatakan kompeten hitung dasar intuitif, keterampilan mengoperasikan hitung dasar aritmetik ini idealnya sudah dikuasai sejak Sekolah Dasar, karena telah menjadi standar kompetensi yang sudah diajarkan dan diharapkan dapat dikuasai sejak kelas 3 Sekolah Dasar, namun belum adanya instrument yang memadai untuk diagnosis dan mengukur keterampilan ini menyulitkan pemetaan secara cepat dan akurat.

Berdasarkan perhitungan data yang telah diproses SPSS 25 dalam penelitian ini, hasil analisis data uji t yang diperoleh $p=0,000(p<0,05)$, sehingga dapat disimpulkan bahwa terdapat perbedaan signifikan antara hasil pretest dan posttest ToSM pada mahasiswa tingkat akhir sesudah pembiasaan aplikasi ToSM selama 15 hari dengan soal operasi hitung tambah, kurang, kali dan bagi.

Sebagai tambahan analisis data dilakukan pula uji signifikansi dan linearitas dari masingmasing operasi hitung menggunakan uji ANOVA. Hasil uji tersebut signifikan, sehingga dapat disimpulkan bahwa habituasi berpengaruh terhadap kompetensi HDI yang ditunjukkan dengan perubahan pada skor ToSM operasi tambah, kurang kali dan bagi pada mahasiswa tingkat akhir dan pengaruhnya bersifat linier. Dari output analisis data juga didapatkan nilai kenaikan mean skor ToSM operasi hitung tambah, kurang, kali dan bagi. Hal ini berarti, hasil skor ToSM dari pre-test dan post-test 79 mahasiswa menunjukkan kenaikan yang signifikant setelah ada pembiasaan selama 15 hari.

Selain sebagai instrument diagnosis, ToSM sekaligus berfungsi meningkatan kompetensi hitung dasar intuitif dengan proses habituasi yang baik dan benar. Hal ini dapat dilihat dari hasil output analisis data dengan adanya kenaikan nilai mean yang signifikan dari skor ToSM operasi hitung tambah, kurang, kali dan bagi antara pre-test dan 
post-test. ToSM versi android sebagai alat untuk asesmen diagnosis kompetensi hitung dasar intuitif bersifat praktis dan cepat karena dapat memberikan gambaran secara lengkap dan untuh dalam waktu yang singkat karena hasilnya langsung bisa diketahui sesaat setelah peserta melakukan diagnosis. Kegiatan Habituasi hitung dasar dengan aplikasi ToSM akan memberikan implikasi positif pada mahasiswa, selain dapat digunakan untuk membangun kompetensi hitung dasar intuitif, kegiatan ini juga dapat meningkatkan kemampuan konsentrasi mahsiswa dan diharapkan dapat meningkatkan Adversity quotient.

\section{Saran}

Untuk pengembangan penelitian ToSM kedepan dalam bidang psikologi, sebelum melakukan pengambilan data, dilakukan rancangan perlakuan data yang lebih matang sehingga memungkinkan peneliti memperoleh lebih banyak informasi dari data yang ada.

Peneliti juga menyarankan agarmerancang penelitian yang bersifat longitudinal untuk membuktikan tidak adanya hubungan antara lamanya mengikuti kuliah di kampus dengan kompetensi hitung dasar intuitif, meskipun terlihat sederhana hanya berupa hitung dasar aritmetika bilangan asli tanpa melibatkan operasi yang sulit. Adapun rancangan penelitian yang dimaksud adalah: (1). Melakukan diagnosis pada mahasiswa tingkat akhir. (2) Melakukan diagnosis pada mahasiswa tingkat awal dan kembali dilakukan diagnosis saat mahasiswa tersebut sudah di tingkat pertengahan kemudian ditingkat akhir. (3) Perbedaan poin 1 dan 2 adalah sifat spontanitas poin 1 yang belum mengenal metode ToSM sama sekali, karena peneliti menduga pengenalan metode ToSM dapat berpengaruh terhadap hasi yang akan dibuktikan pada poin 2 saat mahasiswa tersebut sudah masuk jenjang semester akhir.

Selanjutnya selain untuk keperluan diagnosis dan terapi metode ToSM merupakan alat untuk hiburan para mahasiswa yang memiliki multi manfat diantaranya menjaga kebugaran otak, melatih focus, dan diduga dapat meningkatkan self - esteem dan meningkatkan kompetensi personal sehingga sangat dianjurkan untuk dikenalkan pada setiap mahasiswa(Faz, 2019a).

Peneliti menduga Mahasiswa yang memiliki kompetensi hitung dasar intuitif dengan habituasi menggunakan teknologi ToSM ini dapat meningkatkan Adversity quotient yakni suatu kemampuan seseorang dalam mengatasi kesulitan dan mengubah kesulitan dalam meraih kesuksesan. ToSM yang juga berfungsi meningkatkan ketahanan diri dalam menyelesaikan tugas dengan tingkat beban kesulitan yang rendah sangat 
berpeluang untuk dapat dijadikan pengayaan bagi mahasiswa berlatih AQ dan kemudian perlu dilakukan penelitian lebih lanjut.

\section{Kepustakaan}

Amilia, F. (2018). Pemahaman dan Habituasi untuk Membangun Kompetensi Menulis Praktis dan Ilmiah. Lingua Franca:Jurnal Bahasa, Sastra, Dan Pengajarannya, 2(1). https://doi.org/10.30651/lf.v2i1.1401

Annastasya G. Ratulangi, Bernabas H. R. Kairupan, A. E. D. (2021). Adiksi Internet Sebagai Salah Satu Dampak Negatif Pembelajaran Jarak Jauh Selama Masa Pandemi COVID19. JURNAL BIOMEDIK: JBM, 13(3), 251-258. https://doi.org/10.35790/jbm.13.3.2021.31957

Ariela Estiana. (2019). APLIKASI FOCUS TOSM SEBAGAI SALAH SATU INSTRUMEN MATEMATIKA DETIK BERBASIS ANDROID.

Desi Dwi J, Eleonora Dwi W, W. B. U. (2018). EFEKTIVITAS METODE REKREASI MATEMATIKA DETIK DENGAN LEVEL A2 TERHADAP TINGKAT KESIAPAN BELAJAR SISWA. 5(2), 35-50.

Direktorat Tenaga Kependidikan, D. P. D. (2008). Kriteria dan indikator keberhasilan pembelajaran. 1-49.

DR Kawashima. (2009). Latih Otak Anda Lagi; Meningkatkan Kemampuan Otak, Meningkatkan Memori, Meningkatkan Kreatifitas. Mitra Media.

Endro Tri Susdarwono. (2020). Efektivitas Metode DR Kawashima dalam Meningkatkan Kemampuan Matematika Anak Autis. SPECIAL : Special and Inclusive Education Journal, 1(2), 98-105. https://doi.org/10.36456/special.vol1.no2.a2652

Faz, A. T. (2019a). Matematika Detik, Inspirasi, Fondasi dan Garis Besar (A. M. N. R. Tyas (ed.); 2nd ed.). PT. Aksarra Sinergi Media.

Faz, A. T. (2019b). Matematika Detik Level A “Membaca Angka Secepat Membaca Kata” (Y. A. H. M. M. M. I. Triyanti (ed.); I). PT. Aksarra Sinergi Media.

Faz, A. T. (2020). Modul Instruktur ToSM (Test of Second Mathematics). AKDI Ibadurrahman.

Nisa, M. (2018). Keefektifan Rekreasi Matematika Detik Dengan TOSM (TEST OF SECOND MATHEMATICS) Terhadap Kemampuan Koneksi Matematis Siswa Kelas VII Materi Aritmetika Sosial.

Nur Aristiyo, D., \& Nisa, M. (2020). PENGARUH REKREASI MATEMATIKA DETIK DENGAN TOSM (TEST OF SECOND MATHEMATICS). In Matematika Detik dengan TOMS terhadap kemampuan Koneksi Matematika (Vol. 7, Issue 1). https://journal.peradaban.ac.id/index.php/jdpmat/article/view/531

Pusmenjar. (2020). Buku saku asesmen diagnosis kognitif berkala. 1-10. 
Philanthropy Journal of Psychology

Vol 5 Nomor 1 (2021), 190-205

ISSN 2580-6076 (Print), ISSN 2580-8532 (Online)

Sugiarti, R., Nurlaili, A., \& Febriani, U. F. (2020a). Pengaruh Adversity Quotient terhadap Motivasi Berprestasi pada Siswa Cerdas Istimewa. PHILANTHROPY: Journal of Psychology, 4(1), 82. https://doi.org/10.26623/philanthropy.v4i1.2141

Sugiarti, R., Nurlaili, A., \& Febriani, U. F. (2020b). Pengaruh Adversity Quotient terhadap Motivasi Berprestasi pada Siswa Cerdas Istimewa. PHILANTHROPY: Journal of Psychology, 4(1), 82. https://doi.org/10.26623/philanthropy.v4i1.2141

Sugiarti, R., \& Suhariadi, F. (2015). Gambaran Kompetensi Sosial Siswa Cerdas Istimewa.

Suhariadi, F. (2013). Manajemen Sumber Daya Manusia: Dalam Pendekatan TeoritisPraktis. June, 210.

Tim PPMD. (2021). Overview / Statistik ToSM - Matematika Detik. https://tosm.matematikadetik.com/app/overview

Tohir, M. (2019). Hasil PISA Indonesia Tahun 2018 Turun Dibanding Tahun 2015. https://www.researchgate.net/publication/337717927_Hasil_PISA_Indonesia_Tahu n_2018_Turun_Dibanding_Tahun_2015 